The mission was regarded initially as a 'pilot project', and, in the words of the director, 'Elle a conduit sa barque '; its further activities, however, are uncertain and its continuance is threatened by lack of a permanent location and adequate equipment.

\title{
Corona
}

A MONTHLY journal, primarily designed for members of the British Colonial Service, was started in February 1949 under the editorship of Kenneth Bradley, a member of the Colonial Service, who has served in Northern Rhodesia, Falkland Islands, and Gold Coast. Corona includes articles of general interest to all concerned with colonial administration, as well as book reviews, notes on current affairs in the United Kingdom, and comments and information on social diversions likely to appeal to officers on leave. Shorter articles and verses from time to time illuminate the lightet side of life in colonial territories, and a specially attractive feature of each number are the extremely beautiful and well-chosen photographs illustrating characteristic aspects of various territories. The October number (vol. I, 9) includes an article on the Portuguese African Colonies, initiating a series dealing with the colonial dependencies of different nations. Corona may be ordered from H.M. Stationery Office, P.O. Box 569, London, S.E. I. Annual subscription i 4 s. including postage.

\section{Margaret Wrong Prize}

READERS of this Journal will not need to be reminded of the outstanding work which Margaret Wrong did for the spiritual and cultural development of Africa, to which she devoted the last twenty years of her life. She was particularly concerned, as Secretary of the International Committee on Christian Literature for Africa, in the provision of books to satisfy the demands of the rapidly growing literate public in that continent.

It was felt that many of her friends in Africa and elsewhere would like to perpetuate her memory by the institution of a Prize intended to encourage literary production by Africans. A Committee was formed under the Chairmanship of Sir Gerald Hawkesworth to organize an appeal for funds and to initiate arrangements for awarding the Prize. After the tragic death of the Chairman his place was taken by Mr. Christopher Cox, Educational Adviser to the Secretary of State for the Colonies. The fund is still open and any person or institution desiring to be associated with this project is invited to send a contribution to: THE MARGaret WRONG MEMORIAL FUND, c/o The Rev. Michael Davidson, M.A., Institute of Christian Education, 46 Gordon Square, London, W.C.

It is proposed to offer a Prize annually for original literary work by writers of African race resident in a part of Africa to be determined each year by the Trustees of the Fund. The Prize will be open to competition in 1950 subject to the following regulations:

I. A silver medal and a prize not exceeding $f 5$ will be offered in r950.

2. Manuscripts are invited from the Southern Sudan, Somaliland, Uganda, Kenya, Tanganyika, Zanzibar, and the Belgian Congo.

3. Manuscripts should not be less than 5,000 or more than 15,000 words in length, and may be written in either English or French.

4. Works submitted should be of an imaginative character or descriptive of African life or thought, and suitable for general reading.

5. Manuscripts should be addressed to: THE MARGARET wrong PRIZE, c/o The International Committee on Christian Literature for Africa, 2 Eaton Gate, London, S.W. $x$, and must be received not later than 31 December 1950.

6. The decision of the Trustees will be final. 